JPPUMA: Jurnal Ilmu Pemerintahan dan Sosial Politik UMA (Journal of Governance and Political Social UMA),

7 (2) (2019): 219-226, DOI: http://dx.doi.org/10.31289/ippuma.v7i2.3014

JPPUMA: Jurnal Ilmu Pemerintahan dan Sosial Politik UMA

(Journal of Governance and Political Social UMA)

Available online http://ojs.uma.ac.id/index.php/jppuma

\title{
Realitas Elit Politik Lokal dan Persepsi Masyarakat dalam Proses Pemekaran Daerah
}

\section{Reality of Local Political Elite and Community Perception in Regional Redistricting Process}

\author{
Hilal Ramdhani \\ Program Magister Ilmu Politik, Universitas Indonesia, Indonesia
}

Diterima: 25 Oktober 2019; Disetujui 29 November 2019; Dipublish 1 Desember 2019

\begin{abstract}
Abstrak
Artikel ini bertujuan untuk memahami dan mengidentifikasi belum terbentuknya pemekaran provinsi Cirebon, padahal sudah terdapat wacana pembentukan provinsi Cirebon dengan ditandai adanya pembentukan panitia pemekaran provinsi Cirebon (P4C) sejak tahun 2009. Guna mendekati masalah ini dipergunakan acuan teori elit politik dari Geatano Mosca, teori tersebut menjelaskan bahwa tindakan elit merupakan bentuk dari kehendak masyarakat, sehingga dipahami bahwa adanya keterkaitan antara pandangan masyarakat dengan tindakan yang dilakukan oleh elit politik. Data-data dikumpulkan melalui obervasi tindakan-tindakan elit politik di wilayah Kabupaten Cirebon, Kota Cirebon, Kabupaten Indramayu, Kabupaten Kuningan dan Kabupaten Majalengka, serta melakukan wawancara kepada masyarakat di wilayah Kabupaten Cirebon, Kota Cirebon, Kabupaten Indramayu, Kabupaten Kuningan dan Kabupaten Majalengka. Analisis data dilakukan secara kualitatif yaitu menggunakan reduksi data, penyajian data dan penarikan kesimpulan. Kajian ini menyimpulkan bahwa sampai tahun 2019 elit politik lokal Kab. Majalengka dan Kab, Kuningan masih tidak menyetujui untuk bergabung dengan Provinsi Cirebon, sedangkan elit politik Kab. Cirebon, Kota Cirebon dan Kab, Indramayu sepakat untuk membentuk provinsi Cirebon, keputusan elit politik tersebut ternyata sesuai dengan persepsi masyarakat yang menolak atau mendukung bergabung membentuk Provinsi Cirebon.
\end{abstract}

Kata Kunci: Elit Politik, Politik Lokal, Pemekaran Daerah, Masyarakat, Cirebon.

\begin{abstract}
This article aims to understand and identify that Cirebon Province has not yet been formed, even though there has already been a discourse on the formation of Cirebon Province, marked by the establishment of the Cirebon Province Expansion Committee (P4C) since 2009. In order to approach this problem, the theory of political elite from Geatano Mosca is used, the theory explains that elite action is a form of the will of the community, so that it is understood that there is a link between community views and actions taken by political elites. Data is collected through the observation of the actions of political elites in the regions of Cirebon Regency, Cirebon City, Indramayu Regency, Kuningan Regency and Majalengka Regency, and conducting interviews with the community in the Cirebon Regency, Cirebon City, Indramayu Regency, Kuningan Regency and Majalengka Regency. Data analysis was carried out qualitatively using data reduction, data presentation and drawing conclusions. This study concludes that until 2019 the local political elite of Kab. Majalengka and Kab, Kuningan still did not agree to join the Cirebon Province, while the political elite of Kab. Cirebon, Cirebon City and Regency, Indramayu agreed to form the province of Cirebon, the decision of the political elite turned out to be in accordance with the perception of the people who refused or supported joining to form the Cirebon Province.
\end{abstract}

Keywords: Political Elite, Local Politics, Regional Expansion, Society, Cirebon.

How to Cite: (2019). Realitas Elit Politik Lokal dan Persepsi Masyarakat dalam Proses Pemekaran Daerah. JPPUMA: Jurnal Ilmu Pemerintahan dan Sosial Politik UMA (Journal of Governance and Political Social UMA), 7 (2): 219-226.

${ }^{*}$ Corresponding author: ISSN 2549-1660 (Print)

E-mail: hilal.ramdhani18@gmail.com ISSN 2550-1305 (Online) 


\section{PENDAHULUAN}

Wilayah Cirebon berada di tepian pantai utara Jawa (Pantura) dan memiliki sungai-sungai yang berperan sentral sebagai jalur transportasi yang berada di sekitar Pelabuhan Cirebon yaitu: Sungai Cimanuk, Sungai Pekik, Sungai Kesunean dan Sungai Cilosari (Tim Peneliti Jurusan Sejarah Fakultas Sastra UNPAD, 1991). Sejak tahun 1705, wilayah Cirebon sudah dikuasai oleh Pemerintah Kolonial. Tetapi ketika itu VOC-lah yang pertamakali menguasai wilayah Cirebon sebagai imbalan atas jasanya membantu Pakubuwono I dalam menduduki tahkta Mataram.

Wilayah Karesidenan Cirebon meliputi Indramayu, Gebang, Daerah Kasultanan Cirebon, yang meliputi wilayah yang pada saat ini menjadi Kabupaten Cirebon, Kabupaten Majalengka, Kabupaten Kuningan, serta meliputi tanah partikelir di Kandanghaur dan Indramayu, serta daerah di wiliyah Cirebon-Priangan, yang mencakup wilayah Galuh, Limbangan dan Sukapura. Pada tahun 1870-1900an wilayah Karesidenan Cirebon terdiri dari empat kabupaten, yaitu Kabupaten Cirebon, Kabupaten Majalengka, Kabupaten Kuningan, dan Kabupaten Indramayu (Breman, 1986).

Pada masa kemerdekaan wilayah eks Karesidenan Cirebon terdiri dari empat Kabupaten dan satu Kota yang terletak di Provinsi Jawa Barat, diantaranya Kabupaten Cirebon, Kabupaten Kuningan, Kabupaten Majalengka, Kabupaten Indramayu dan Kota Cirebon.

Sejak era reformasi diterapkan di Indonesia pada tahun 1998, pemahaman mengenai demokrasi terbuka dan memberikan wewenang kepada daerah untuk mengurusi daerahnya yakni melalui otonomi daerah yang dipahami sebagai sebuah proses devolusi pada sektor publik yaitu dengan terjadinya proses pelimpahan wewenang dari pemerintah pusat kepada pemerintah daerah. Hal itu menandakan, pemekaran daerah diartikan sebagai proses pelimpahan wewenang kekuasaan dari pemerintah pusat kepada pemerintah daerah (Febriyandi, 2015).

Perkembangan isu politik di tingkat nasional maupun lokal terkait dengan pemekaran wilayah terus menjadi wacana politik yang muncul dari berbagai wilayah di Indonesia walaupun masih dalam moratorium pemerintah pusat. Fenomena politik tersebut dikarenakan adanya tekanan politik seperti perasaan dan keinginan untuk mandiri dari kalangan elit politik lokal maupun masyarakat di wilayah tersebut. Alasan yang menjadi faktor penting dalam proses pemekaran daerah ialah untuk mensejahterakan rakyat karena secara tingkat ekonomi, daerah yang memiliki keinginan untuk dimekarkan berada tertinggal jauh dari daerah lainnya, serta adanya alasan political history yang menjadi dasar elit politik untuk melakukan pemekaran daerah (Muqoyyidin, 2013).

Berdasarkan Pasal 1 Peraturan Pemerintah Republik Indonesia Nomor 78 Tahun 2007 Tentang Tata Cara Pembentukan, Penghapusan, dan Penggabungan Daerah menjelaskan bahwa Pemekaran daerah adalah pemecahan provinsi atau kabupaten/kota menjadi dua daerah atau lebih. Selama tahun 1999 sampai sekarang sudah terjadi delapan pemekaran provinsi.

Syarat administratif untuk melakukan pemekaran daerah dalam Pasal 5 ayat (1) Peraturan Pemerintah No 78 tahun 2007 tentang tata cara pembentukan, penghapusan, dan penggabungan daerah menyebutkan bahwa pembentukan Provinsi baru perlu memiliki keputusan dari masing-masing DPRD kabupaten/kota yang akan menjadi bagian dari wilayah calon provinsi baru berkaitan dengan persetujuan pembentukan calon provinsi baru berdasarkan hasil Rapat Paripurna, Keputusan bupati/walikota ditetapkan dengan keputusan bersama bupati/walikota wilayah calon provinsi 
mengenai persetujuan pembentukan calon provinsi baru, Keputusan DPRD provinsi induk yang terkait dengan persetujuan pembentukan calon provinsi baru yang diberdasarkan pada hasil Rapat Paripurna, Keputusan Gubernur mengenai persetujuan yang terkait dengan pembentukan calon provinsi baru, Rekomendasi Menteri. Dalam Pasal 8 Peraturan Pemerintah No 78 tahun 2007 tentang tata cara pembentukan, penghapusan, dan penggabungan daerah menyebutkan bahwa cakupan wilayah pembentukan provinsi paling sedikit 5 (lima) kabupaten/kota.

Tabel 1. Daftar Provinsi Hasil Pemekaran Daerah dari Tahun 199 sampai sekarang

\begin{tabular}{|c|c|c|}
\hline Provinsi & Ibu Kota & $\begin{array}{l}\text { Waktu } \\
\text { Peresmian }\end{array}$ \\
\hline Maluku & Sofifi-Ternate & $\begin{array}{ll}4 & \text { Oktober } \\
1999 & \end{array}$ \\
\hline Banten & Serang & $\begin{array}{ll}17 & \text { Oktober } \\
2000 & \end{array}$ \\
\hline $\begin{array}{l}\text { Kepulauan } \\
\text { Bangka } \\
\text { Belitung }\end{array}$ & Pangkal Pinang & $\begin{array}{l}4 \quad \text { Desember } \\
2000\end{array}$ \\
\hline Gorontalo & Gorontalo & $\begin{array}{l}22 \text { Desember } \\
2000\end{array}$ \\
\hline $\begin{array}{l}\text { Irian Jaya } \\
\text { Barat }\end{array}$ & Manokwari & $\begin{array}{l}21 \text { November } \\
2001\end{array}$ \\
\hline $\begin{array}{l}\text { Kepulauan } \\
\text { Riau }\end{array}$ & Tanjung Pinang & $\begin{array}{ll}25 & \text { Oktober } \\
2002 & \end{array}$ \\
\hline $\begin{array}{l}\text { Sulawesi } \\
\text { Barat }\end{array}$ & Mamuju & $\begin{array}{ll}5 & \text { Oktober } \\
2004 & \end{array}$ \\
\hline $\begin{array}{l}\text { Kalimantan } \\
\text { Utara }\end{array}$ & Tanjung Selor & $\begin{array}{ll}25 & \text { Oktober } \\
2012 & \end{array}$ \\
\hline
\end{tabular}

Sumber Tabel diolah Peneliti, 2019

Berdasarkan peraturan tersebut menandakan bahwa peran elit sangat penting dalam membentuk provinsi Cirebon, hal itu sesuai dengan teori elit Geatano Mosca bahwa elit politik memiliki kewenangan dalam membentuk keputusan politik, sehingga ketika dalam kelompok elit tidak terjadi kesepakatan politik, maka berakibat pada kegagalan keputusan politik.

Fokus masalah dalam penelitian ini yaitu konflik elit politik di wilayah Kabupaten Majalengka, Kabupaten Kuningan, Kabupaten Indramayu,
Kabupaten Cirebon dan Kota Cirebon dalam proses pemekaran daerah sejak tahun 2009 sampai 2019. Selain itu, untuk melengkapi kajian pemekaran daerah provinsi Cirebon, dibahas mengenai persepsi masyarakat di wilayah Kabupaten Majalengka, Kabupaten Kuningan, Kabupaten Indramayu, Kabupaten Cirebon dan Kota Cirebon terkait pemekaran provinsi Cirebon, karena dalam teori elit Geatano Mosca, perilaku elit dalam memutuskan keputusan politik merupakan bentuk dari kehendak masyarakat.

\section{METODE PENELITIAN}

Pendekatan kualitatif digunakan dalam penelitian dengan tidak dibatasi pada kategori-kategori tertentu dalam pengumpulan datanya, sehingga peneliti dapat mempelajari dan menemukan isuisu secara mendalam terkait dengan masalah yang diteliti. Penggunaan penelitian kualitatif ditujukan agar peneliti tidak berusaha untuk memanipulasi data, akan tetapi data diambil secara natural.

Metode penelitian yang digunakan dalam penelitian ini yaitu, studi kasus yang fokus pada hasil penelitian kasus mengenai konflik elit dan persepsi masyarakat dalam proses pemekaran daerah di wilayah Kabupaten Majalengka, Kabupaten Indramayu, Kabupaten Kuningan, Kabupaten Cirebon dan Kota Cirebon. Ruang lingkup dari studi kasus ini mencakup keseluruhan siklus kegiatan politik elit dan masyarakat yang dikarenakan adanya penekanan terhadap faktor-faktor kasus tertentu yang meliputi keseluruhan faktor-faktor dan fenomenafenomena politik daerah (Nazir, 2011).

Penelitian ini dilakukan selama 3 (tiga) bulan yaitu Juni, Juli dan Agustus untuk mendapatkan informasi dari informan di 5 (lima) wilayah yaitu Kota Cirebon, Kab. Cirebon, Kab. Indramayu, Kab. Kuningan dan Kab. Majalengka.

Subjek dalam penelitian ini sebanyak 25 orang yang dibagi dalam 5 wilayah yaitu Kota Cirebon, Kab. Cirebon, 
Kab. Indramayu, Kab. Kuningan dan Kab. Majalengka. Subjek penelitian berasal dari kalangan mahasiswa dan pekerja (pedagang dan karyawan swasta). Pengambilan subjek penelitian tersebut dilakukan karena menjadi bagian penting dalam perkembangan daerah di kawasan Ciayumajakuning.

Penelitian ini memiliki 10 langkah, diantaranya: a) pemilihan tema, b) pembacaan literatur, c) perumusan fokus dan masalah penelitian, d) pengumpulan data, e) penyempurnaan data, f) pengolahan data, g) analisis data, h) dialog teoritik, i) triangulasi temuan dan j) simpulan hasil penelitian.

Data yang dikumpulkan berupa narasi, rekaman maupun dokumentasi. Peneliti menggunakan pedoman wawancara, pedoman observasi dan studi dokumentasi. Selain itu, Peneliti juga menggunakan alat bantu untuk mempermudah penelitian, diantaranya: 1) Buku catatan (notebook), yang berfungsi untuk mencatat dalam proses wawancara, observasi maupun kegiatan lain yang berkenaan dengan proses pengumpulan data. 2) Tape recorder, yang digunakan oleh Peneliti untuk merekam pada saat wawancara dengan narasumber, sehingga akurasi data lebih valid. 3) Kamera, yang digunakan dalam setiap kegiatan penelitian, baik dalam proses wawancara, observasi dan kegiatan lain yang berkenaan dengan proses penelitian.

Teknik pengumpulan data dalam penelitian ini mengunakan tiga cara yaitu wawancara, observasi langsung dan dokumentasi.

Pengumpulan data dalam penelitian ini menggunakan observasi langsung dengan cara pengambilan data melihat realita elit dan pandangan-pandangan masyarakat terkait pemekaran daerah. Wawancara yang digunakan dalam penelitian ini bersifat baku terbuka yang bercirikan urutan setiap pertanyaan, katakata yang digunakan, serta kesamaan penyajian untuk setiap responden (Nazir,
2011). Teknik dokumentasi dalam penelitian ini diperoleh melalui dokumendokumen resmi hasil risalah dan pernyataan elit politik di media sosial (Arikunto, 2006).

Proses analisis data dalam pelitian ini akan dilakukan secara terus menerus dari awal sampai akhir penelitian, baik di lapangan maupun di luar lapangan. Analisis data berlangsung bersamaan dengan proses pengumpulan data. Diantaranya yaitu reduksi data, penyajian data dan simpulan/verifikasi. Namun ketiga tahapan tersebut berlangsung secara simultan (Bugin, 2001).

Tahap pertama dalam melakukan analisis data ialah menggunakan reduksi data yang dilakukan menggunakan cataan atau telaah kembali mengenai seluruh catatan lapangan yang diperoleh dari hasil wawancara, obversavi maupun dokumentasi kedalam laporan yang rinci. Reduksi data ini berlangsung berkelanjutan selama pengambilan data berlangsung. Tujuan dari reduksi data untuk membuang yang tidak perlu, menajamkan, menggolongkan, mengarahkan dan mengorganisasi data, sehingga terdapat kesimpulan final yang dapat ditarik dan diverifikasi (Milles dan Hubberman, 1992).

Alur penting dari kegiatan analisis data adalah penyajian data yang membatasi pada suatu penyajian sebagai sekumpulan informasi tersusun yang memberi kemungkinan adanya penarikan kesimpulan dan pengambilan keputusan.

Langkah ketiga dalam analisis data kualitatif yaitu penarikan kesimpulan dan verifikasi (Milles dan Hubberman, 1992). Penarikan kesimpulan ini dilakukan berdasarkan pengumpulan data, yang telah diperoleh melalui wawancara, observasi dan dokumentasi yang telah di reduksi dan penyajian data.

\section{HASIL DAN PEMBAHASAN}

Dalam kasus proses pemekaran provinsi Cirebon dimulai pada tahun 2009 sampai 
sekarang, tepatnya ketika pembentukan provinsi Cirebon dideklarasikan. Sejumlah perwakilan dewan yang datang menyatakan persetujuannya terhadap pembentukan Provinsi Cirebon. Deklarasi dilakukan oleh Presidium Pembentukan Provinsi Cirebon (P3C) di sebuah ballroom hotel di kawasan Jalan Tuparev, Kabupaten Cirebon. Terlihat sekitar 1.000 orang dan seluruh Panitia Pendukung Pembentukan Provinsi Cirebon (P4C) hadir. Juga terlihat perwakilan Dewan Perwakilan Rakyat Daerah antara lain Ketua Dewan Perwakilan Kabupaten Cirebon, Tasiya Soemadi Al Gotas, Wakil Ketua Dewan Perwakilan Kota Cirebon Edi Suripno, Wakil Ketua Dewan Perwakilan Majalengka M Iqbal, dan Ketua Dewan Perwakilan Kabupaten Indramayu, Hasim Junaidi. Satu-satunya perwakilan anggota dewan daerah yang tidak hadir di wilayah Cirebon adalah dari Kabupaten Kuningan (Tempo, 2009).

Proses pembentukan Provinsi Cirebon masih dalam tahap persetujuan di tingkat Kabupaten dan Kota, karena belum ada persetujuan secara politik untuk membentuk provinsi Cirebon dari Kabupaten Majalengka dan Kuningan. Sedangkan, Kabupaten Indramayu, Kota Cirebon dan Kabupaten Cirebon sudah memiliki persetujuan politik untuk membentuk provinsi Cirebon. Padahal untuk terbentuknya sebuah provinsi baru, berdasarkan Pasal 8 Peraturan Pemerintah No 78 tahun 2007 minimal harus ada lima kabupaten dan atau kota.

Terkait pemekaran daerah Provinsi Cirebon, Sutrisno sebagai Bupati Majalengka dua periode yakni 2008-2013 dan 2013-2018 mengingatkan agar para penggagas tidak mengait-ngaitkan Provinsi Cirebon dengan keberadaan Kabupaten Majalengka. Sutrisno menegaskan bahwa Kabupaten Majalengka tidak akan bergabung dengan provinsi Cirebon dan tetap menjadi bagian dari Provinsi Jawa Barat. Untuk memenuhi syarat administrasi, Sutrisno menyarankan kepada penggagas pemekaran provinsi Cirebon untuk melakukan pemekaran Kabupaten terlebih dahulu, jika jumlah kabupaten yang mendukung pembentukan Provinsi Cirebon tidak memenuhi syarat administrasi. Walaupun adanya sejarah Kabupaten Majalengka yang masuk ke dalam kekuasaan Sunan Gunung Djati, hal itu tidak bisa menjadi alasan para penggagas provinsi Cirebon untuk mencatumkan Kabupaten Majalengka ke dalam rencana pemekaran provinsi Cirebon (Nastain, 2012).

Kondisi tersebut menandakan adanya peran elit politik yang mengakibatkan tidak bisa terwujudnya provinsi Cirebon, hal itu memicu suatu gagasan baru untuk melakukan pemekaran dua kabupaten baru, yaitu Kabupaten Indramayu Barat dan Kabupaten Cirebon Timur. Hal ini dimaksudkan untuk membentuk provinsi Cirebon tanpa harus memasukkan Kab. Majalengka dan Kab. Kuningan ke dalam wilayah Provinsi Cirebon.

Berdasarkan kasus pemekaran provinsi Cirebon, elit politik memiliki peran penting dalam pengambilan suatu keputusan. Teori elit menjelaskan bahwa elit politik merupakan realitas yang ada dalam setiap masyarakat. Pareto (1935) menyatakan bahwa setiap masyarakat selalu diperintah oleh sekelompok kecil orang yang mempunyai kualitas-kualitas yang dapat memberikan efek pada kekuasaan sosial dan politik. Kelompok kecil inilah yang dikenal sebagai elit. Elit merupakan orang-orang yang mampu menduduki jabatan tinggi dalam lapisan masyarakat. Lebih lanjut, Pareto menyatakan bahwa masyarakat terdiri dari dua kelas, yaitu lapisan atas yang terbagi ke dalam elit yang memerintah dan elit yang tidak memerintah, serta lapisan yang lebih rendah, yaitu nonelit.

Pendapat hampir sama dikemukakan oleh Mosca (1939) yang menjelaskan bahwa dimana lapisan elit yang berkuasa atau disebut political elite. Elit politik ini merupakan kelompok terorganisir yang memiliki kewenangan politik. Kelas elit terdiri dari minoritas terorganisir yang akan memaksakan kehendaknya melalui manipulasi maupun kekerasan, khususnya dalam demokrasi. Elit politik memiliki semua fungsi politik, dapat monopoli kekuasaan dan menikmati setiap keuntungan dari kekuasaan yang diperoleh. Kekuasaan elit yang dimiliki 
tidak berasal dari komunitas atau posisi ekonomi, akan tetapi dari organisasi yang berhubungan dengan kekuasaan publik negara, tindakan elit politik terbentuk atas dasar kehendak masyarakat.

Berdasarkan data yang diperoleh menunjukkan bahwa persepsi masyarakat di lima daerah yang dilakukan penelitian menunjukkan hasil yang berbeda. Terdapat suatu hasil penelitian yang menunjukkan bahwa perbedaan pandangan antar masyarakat mencerminkan keinginan elit politik dalam mengambil suatu keputusan, dalam hal ini terdapat suatu fenomena politik yang menandakan adanya permasamaan antara keinginan masyarakat dan keinginan elit politik daerah.

Peneliti mengelompokan persepsi masyarakat berdasarkan sikap elit politik daerah dalam menyikapi pemekaran daerah provinsi Cirebon, yaitu masyarakat Kota Cirebon, Kab. Cirebon dan Kab. Indramayu, serta masyarakat Kab. Majalengka dan Kab. Kuningan.

Masyarakat Kab. Majalengka semua informan yang dilakukan wawancara menolak untuk berpisah dengan Jawa Barat, alasan tersebut didasarkan pada aspek budaya yang memiliki bahasa daerah sunda, sehingga mereka merasa lebih setuju bila tetap bergabung dengan Jawa Barat.

Masyarakat Kab. Majalengka juga menganggap bahwa pemekaran daerah tidak serta merta akan menghasilan pemerataan ekonomi, karena beberapa Provinsi hasil pemekaran seperti Banten tidak menghasilkan pemerataan ekonomi, bahkan cenderung menghasilkan dinasti politik kekeluargaan, hal itu dianggap akan mengancam hak-hak demokrasi masyarakat.

Alasan identasi kebudayaan serta kekhawatiran kemunculan dinasti politik kekeluargaan mengakibatkan masyarakat Kab. Majalengka memilih untuk tetap bergabung dengan Jawa Barat.

Pandangan masyarakat Kab. Kuningan sangat menarik karena secara geografis dan akses transportasi Kab. Kuningan lebih dekat dengan Cirebon. Pandangan masyarakat
Kuningan beranggapan pemekaran Provinsi Cirebon hanya akan menjadikan rebutan kekuasaan alit politik, sehingga masyarakat menganggap bahwa dengan adanya pemekaran daerah tidak serta merta menjamin pemekaran ekonomi.

Bukan hanya pada aspek politik, masyarakat Kab. Kuningan juga lebih memilih menjadi bagian dari Jawa Barat karena alasan budaya yang sama yaitu Sunda, sedangkan wilayah Cirebon memiliki budaya Jawa. Hal itu merupakan aspek yang penting bagi masyarakat Kab. Kuningan untuk tetap memilih bertahan dengan Jawa Barat.

Berdasarkan masyarakat

Kab. Majalengka dan Kab. Kuningan, menandakan bahwa identitas kebudayaan menjadi faktor paling penting yang mengakibatkan keenganan untuk bergabung mendukung pemekaran provinsi Cirebon. Dalam fenomena tersebut menandakan bahwa pada tingkat politik lokal, identitas kebudayaan lebih digunakan oleh masyarakat daripada kepentingan politik.

Pandangan masyarakat Kota Cirebon, Kab. Cirebon dan Kab. Indramayu yang berdasarkan pandangan elit politik lebih memilih untuk membentuk pemekaran daerah menjadi provinsi Cirebon. Bahkan penggerak dari pemekaran daerah ialah Sultan Kasepuhan Cirebon, Sultan Sepuh XIV Pangeran Raja Adipati (PRA) Arief Natadiningrat yang berasal dari Cirebon.

Masyarakat Kab. Indramayu yang merupakan wilayah dekat dengan Cirebon, bahkan akses transportasi Kab. Indramayu lebih cepat menuju Cirebon daripada Bandung yang menjadi Ibu Kota Jawa Barat. Masyakat Indramayu juga memiliki budaya Jawa, sehingga masyarakat Kab. Indramayu dalam konteks Jawa Barat berada dalam suatu perbedaan yang sangat mencolok.

Atas dasar kondisi tersebut masyarakat Kab. Indramayu sebagian besar memilih setuju untuk adanya pemekaran daerah, hal tersebut didasarkan karena akses kepada Cirebon lebih mudah daripada akses menuju Bandung. Selain itu, adanya kesamaan suku Jawa dengan masyarakat di sebagian wilayah 
Cirebon merupakan aspek penting agar adanya kesamaan identitas suku dalam membentuk provinsi Cirebon.

Pandangan masyarakat Kota dan Kabupaten Cirebon yaitu setuju dengan adanya pemekaran daerah Provinsi Jawa Barat karena dianggap akan membuat kesejahteraan masyarakat, khususnta masyarakat Cirebon, karena pemerintah Provinsi berdekatan dengan masyarakat.

Keberhasilan dalam membangun desentralisasi politik di Indonesia, bukan diukur dari seberapa banyak munculnya daerah otonom (Simanjuntak, 2015), karena pada realitas pemekeran daerah akan menghasilan permasalahan baru di daerah. Penelitian Muqoyyidin (2013) menunjukkan maraknya pemekaran pasca reformasi berdampak pada aspirasi, keberagaman, dan otonomi lokal, yang sulit untuk direalisasikan pada masa orde baru. Akan tetapi, fenomena pemekaran wilayah memberikan efek domino kepada wilayah lain membuat suatu permasalahan di tingkat lokal (Akbar, 2019). Hal tersebut dikarenakan, setiap pemekaran daerah baru akan membawa implikasiimplikasi yang luas sebagai bentuk dari perubahan struktur pemerintahan, perubahan anggaran belanja pemerintah, batas dan nama wilayah, pembagian sumber penerimaan dan pendapatan daerah yang sebelumnya menginduk kepada daerah asal. Perubahanperubahan tersebut, walaupun secara legalitas telah diatur berdasarkan undang-undang, namun dalam praktiknya mengalami berbagai kendala. Munculnya daerah otonomi baru, berarti adanya perubahan otoritas (Sulistiowati, 2014), adanya pengurangan anggaran belanja pemerintah (Prakosa, 2004), penurunan penerimaan dan pendapatan asal, dan yang pasti berkurangnya luas wilayah (Hidayati, 2017). Hal ini apabila tidak diperhatikan secara seksama dalam proses pembentukan daerah otonom baru berpotensi akan memicu konflik lintas daerah (Riyadi, 2009).

Konflik elit dalam proses pemekaran daerah sangat terlihat sisi pragmatisnya ketika terjadi pemilihan kepala daerah, disana akan muncul konflik elit untuk berebut kekuasaan tertinggi daerah yang berhasil mendapatkan otonomi (Rozi, 2016). Seperti penelitian yang dilakukan Qodi (2012) di Maluku Utara yang merupakan wilayah pemekaran sejak tahun 1999 yang lalu dan sampai 2012 terdapat wilayah yang tidak kunjung selesai karena pemekaran tersebut. Persoalan pemekaran wilayah kemudian terus ramai menjadi konsumsi politik ketika menghadapi Pemilukada (Pemilu Bupati maupun Kota) juga Pemilu Legislatif demikian ramai diperebutkan oleh masing-masing kandidat dengan latar belakang etnis dan agama yang terdapat di Maluku Utara.

\section{SIMPULAN}

Elit memiliki kewenangan dalam memutuskan keputusan politik, sebagaimana yang diungkapkan oleh Geatano Mosca. Dalam kasus pemekaran provinsi Cirebon, sudah dilakukan sejak tahun 2009 dan sampai sekarang masih mengalami kendala persetujuan dari Kabupaten Majalengka dan Kabupaten Kuningan yang menolak untuk bergabung menjadi bagian dari Provinsi Cirebon. Hal tersebut mengakibatkan pada belum terbentuknya provinsi Cirebon.

Kondisi elit yang berkonflik antara setuju dan tidak setuju dengan adanya pemekaran daerah, sesuai dengan persepsi masyarakat di wilayah Kabupaten Majalengka dan Kabupaten Kuningan yang tidak setuju adanya pemekaran provinsi Cirebon dan masyarakat Kabupaten Indramayu, Kabupaten Cirebon dan Kota Cirebon. Hal ini sesuai dengan teori Geatano Mosca bahwa tindakan elit terbentuk atas kehendak masyarakat.

Kabupaten Majalengka dan Kabupaten Kuningan merupakan bagian penting dari proses pemekaran provinsi Cirebon, karena dalam Pasal 8 Peraturan Pemerintah No. 78 tahun 2007 tentang tata cara pembentukan, penghapusan, dan penggabungan daerah menyebutkan bahwa cakupan wilayah pembentukan provinsi paling sedikit 5 (lima) 
kabupaten/kota. Kondisi tersebut menandakan bahwa political history suatu daerah tidak serta merta akan memudahkan keputusan elit untuk membentuk suatu daerah otonom baru.

\section{DAFTAR PUSTAKA}

Akbar, S. (2019). Analisa Masalah-Masalah Yang Muncul Dalam Pemekaran Wilayah Baru Pada Penyelengaraan Otonomi Daerah. JIAGANIS, 3(1): 1-15.

Arikunto, S. (2006). Prosedur Penelitian: Suatu Pendekatan Praktek. Jakarta: Rineka Cipta.

Breman, J. (1986). Penguasaan Tanah dan Tenaga Kerja Jawa di Masa Kolonial. Jakarta: LP3ES.

Bugin, B. (2007). Penelitian kualitatif, komunikasi, ekonomi, kebijakan, publik dan ilmu sosial lainnya. Jakarta: Kencana.

Febriyandi, D. (2015). Proses Perumusan Kebijakan Pemekaran Daerah (Studi di PulauSebatik Kabupaten Nunukan Kalimantan Utara). JPP (Jurnal Politik Profetik), 3(2): 68-88.

Hidayati, D. A. (2017). Evaluasi Kebijakan Pemekaran Daerah Kabupaten Lampung Barat. Administratio: Jurnal Ilmiah Administrasi Publik dan Pembangunan, 8(1): 35-44.

Milles \& Hubberman. (2007). Analisis Data Kualitatif. Jakarta: Universitas Indonesia.

Mosca, G. (1939). The Ruling Class. New York: McGraw Hill.

Muqoyyidin, A. W. (2013). Pemekaran wilayah dan otonomi daerah pasca reformasi di Indonesia: Konsep, Fakta Empiris dan rekomendasi ke Depan. Jurnal Konstitusi, 10(2): 287-310.

Nastain, I. (2012). Majalengka Ogah Ikut Wacana Provinsi Cirebon. [online]. Diakses dari https://news.okezone.com/read/2012/01/2 8/340/565334/majalengkaogah-ikutwacana-provinsi-cirebon
Nazir, M. (2011). Metode Penelitian. Bogor: Ghalia Indonesia.

Pareto, Vilfredo. (1935). The Mind and Society. A Treatise on General Sociology. New York: Dower.

Prakosa, K. B. (2004). Analisis pengaruh dana alokasi umum (DAU) dan pendapatan asli daerah (PAD) terhadap prediksi belanja daerah (studi empirik di wilayah propinsi Jawa Tengah dan DIY). Indonesian Journal of Accounting and Auditing, 8(2): 101-118.

Qodi, Z. (2012). Involusi Politik Pemekaran, Etnisitas, Dan Agama: Tantangan Reformasi Birokrasi Kasus Maluku Utara. Jurnal Bina Praja: Journal of Home Affairs Governance, 4(4): 217-226.

Riyadi, S. (2009). Analisis pemekaran wilayah dan potensi konflik di Kabupaten Donggala. Academica, 1(2): 200-221.

Rozi, S. (2016). Merentas Jalan Panjang Perdamaian: Negara \& Masyarakat Dalam Resolusi Konflik. Jurnal Penelitian Politik, 3(1): 77-89.

Simanjuntak, K. M. (2015). Implementasi Kebijakan Desentralisasi Pemerintahan di Indonesia. Jurnal Bina Praja: Journal of Home Affairs Governance, 7(2): 111-130.

Sulistiowati, R. (2014). Implementasi Desentralisasi dan Otonomi Daerah pada Daerah Otonomi Baru (DOB). Sosiohumaniora, 16(3), 270282.

Tempo. (2009). Presidium Pembentukan Provinsi Cirebon Deklarasikan Provinsi Cirebon. [online]. Diakses dari https://nasional.tempo.co/read/163726/pr esidium-pembentukan-provinsicirebondeklarasikan-provinsi-cirebon

Tim Peneliti Jurusan Sejarah Fakultas Sastra UNPAD. (1991). Sejarah Cirebon Abad Ketujuh Belas. Bandung: UNPAD \& PEMDA Jawa Barat. 